\title{
Morphology and morphometry of upland lakes over lateritic crust, Serra dos Carajás, southeastern Amazon region
}

\author{
MARCIO S. DA SILVA ${ }^{1}$, JOSÉ T.F. GUIMARÃES ${ }^{1}$, PEDRO W.M. SOUZA FILHO ${ }^{1,2}$, WILSON \\ NASCIMENTO JÚNIOR ${ }^{1}$, PRAFULLA K. SAHOO ${ }^{1}$, FRANCISCO R. DA COSTA ${ }^{2,3}$, RENATO \\ O. SILVA JÚNIOR ${ }^{1,4}$, TARCÍSIO M. RODRIGUES ${ }^{5}$ and MARLENE F. DA COSTA ${ }^{5}$

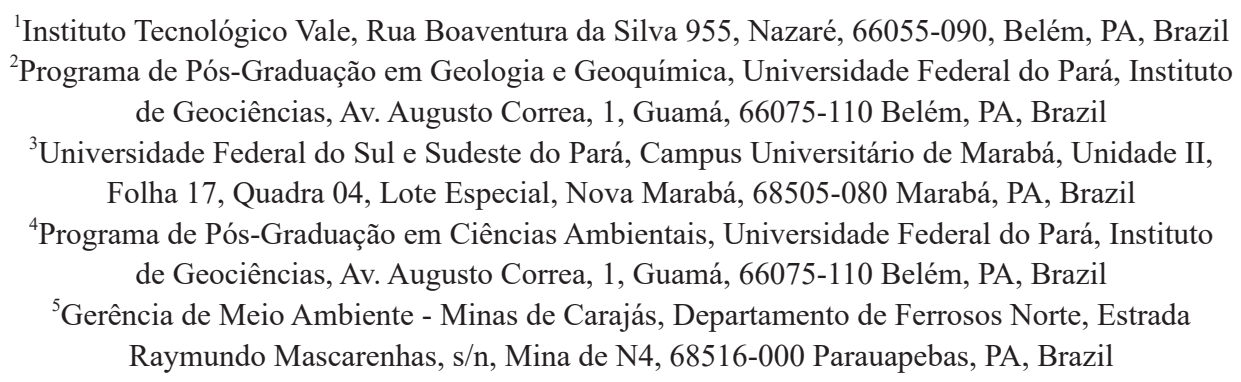

Manuscript received on May 15, 2017; accepted for publication on October 27, 2017

\begin{abstract}
High-resolution satellite images, digital elevation models, bathymetric and sedimentological surveys coupled with statistical analysis were used to understand the physical environment and discuss their influence on water quality of the five upland lakes of Serra Sul dos Carajás, southeast Amazonia. The lakes have midaltitude ranges (elevation), very small (catchment) and shallow to very shallow (central basins). Based on the length, area and volume, Violão and TI (Três Irmãs)-3 lakes may present large vertical movements of the water due to wind action and weakly stratified waters. Trophic conditions based on depth and shore development $\left(\mathrm{L}_{\mathrm{d}}\right)$ parameters must be used with caution, since Amendoim Lake is relatively deep, but it is oligotrophic to ultra-oligotrophic. $\mathrm{L}_{\mathrm{d}}$ values suggest that the lakes are circular to subcircular and are likely formed by solution process, as also suggested by volume development. TI-2 Lake is only presenting convex central basin and has highest dynamic ratio (DR), thus it may have high sedimentation and erosion rates. Based on the relationship between studied parameters, morphometric index and DR likely influence temperature and dissolved oxygen of waters of TI-2 Lake due to its depth profile and wind-induced surface mixing. Nevertheless, water quality parameters are controlled by catchment characteristics of the lakes.
\end{abstract}

Key words: Lateritic crust, lakes, limnology, geomorphology, Amazon region, Carajás.

\section{INTRODUCTION}

Understanding physical characteristics of lake system related to morphometric and morphological

Correspondence to: José Tasso Felix Guimarães

E-mail: tasso.guimaraes@itv.org features is crucial to comprehend its hydrological pattern, structure and ecological functionality (Håkanson 1981, Sperling 1999, Nõges 2009). The lake morphometry is highly influenced by various environmental variables such as nutrient balance, biological productivity and dispersion, 
thermal stability and stratification of the water column, circulation and sedimentary processes (e.g. Panosso et al. 1995, Beisner et al. 2006, Håkanson 2004, Smith et al. 2005, Genkai-Kato and Carpenter 2005, Fantin-Cruz et al. 2008, Souza Filho et al. 2016). Lake morphometric data are also required for a precise evaluation of sediment accumulation rates, dispersion patterns, sensitivity and resilience due to pollutant input in lake systems (Håkanson 1999). The interactions between these environmental variables may significantly vary depending on the lake characteristics. Therefore, large lakes may be separated into sub ecosystems where different key organisms dominate, while smaller lakes (area $<10 \mathrm{~km}^{2}$ ) can often be regarded as single ecosystems (Håkanson 1999, Buraschi et al. 2005). The same must be expected for lowland and upland lakes of the Amazon region (Junk et al. 1989, Lopes et al. 2011, Brito et al. 2014, Sahoo et al. 2016a).

Lowland lakes are widespread on floodplains of the Amazon basin, where they are influenced by annual flood pulse of the rivers according to climate seasonality (Junk 1997). Thus, they receive huge amounts of suspended material from different sources, which are likely located hundreds of kilometers distant during high-stand conditions (Lesack and Melack 1995). On the other hand, upland lakes can only be found in scattered sectors of the Brazilian Amazon (e.g. Seis Lagos, Cordeiro et al. 2011 and Serra Sul de Carajás, Sahoo et al. 2015, 2016a, b). The upland lakes of the Serra Sul dos Carajás were developed over lateritic crusts located above $600 \mathrm{~m}$ in altitude. These lakes were formed by structural and degradation processes of lateritic profiles (Maurity and Kotschoubey 1995), producing sinkhole (solution) lakes and catchment basins hydrologically restricted. However, studies about morphological and morphometric characteristics of upland lakes of Serra Sul de Carajás are surprisingly unknown (Sahoo et al. 2017). Therefore, the present study aims to analyze morphological pattern and morphometric characteristics and their influence on limnology of five upland lakes (Violão, Amendoim, Três Irmãs (TI-1, TI-2 and TI-3) in the Serra Sul de Carajás, southeastern Amazon region.

\section{STUDY AREA}

Violão, Amendoim, and Três Irmãs (TI-1, TI-2, and TI-3) lakes are situated in the southern ridge of the Serra dos Carajás into the Carajás National Forest (namely Flona-Carajás), a law-protected area located in the southeastern Amazon region, Brazil (Figure 1a, b). This region represents a metallogenic province on a global scale (Tolbert et al. 1971) and a major Archean tectonic province of the Amazonian Craton (Macambira and Lafon 1995, Rämö et al. 2002). The large iron deposits occur associated with the Carajás Formation, a dominant volcano-sedimentary sequence that host significant band-iron formation (Olszewski et al. 1989). An extensively weathering profile was formed due to the laterization of the Carajás Formation under humid climate conditions. This developed fragile zones associated with preexisting fractures, which evolved into sinkhole and lakes (Maurity and Kotschoubey 1995).

The lakes are hydrologically restricted and developed over lateritic crust, which is vegetated by ferruginous montane savanna and bordered by Amazon rainforest (Figure 1c-g). The predominance of montane savanna from Serra Sul de Carajás is mainly related to edaphic conditions (Nunes et al. 2015, Skirycz et al. 2014, Guimarães et al. 2014). The occurrence of extensive lateritic crusts and low water retention allowed the widespread development of plant species adapted to nutrient and hydric stress and hindered the colonization of tree species. Consequently, small patches of forest (capão de mata) occur along structural features or over different lithologies that are much more sensitive to weathering and where a thicker soil horizon was developed, with higher nutrient and 

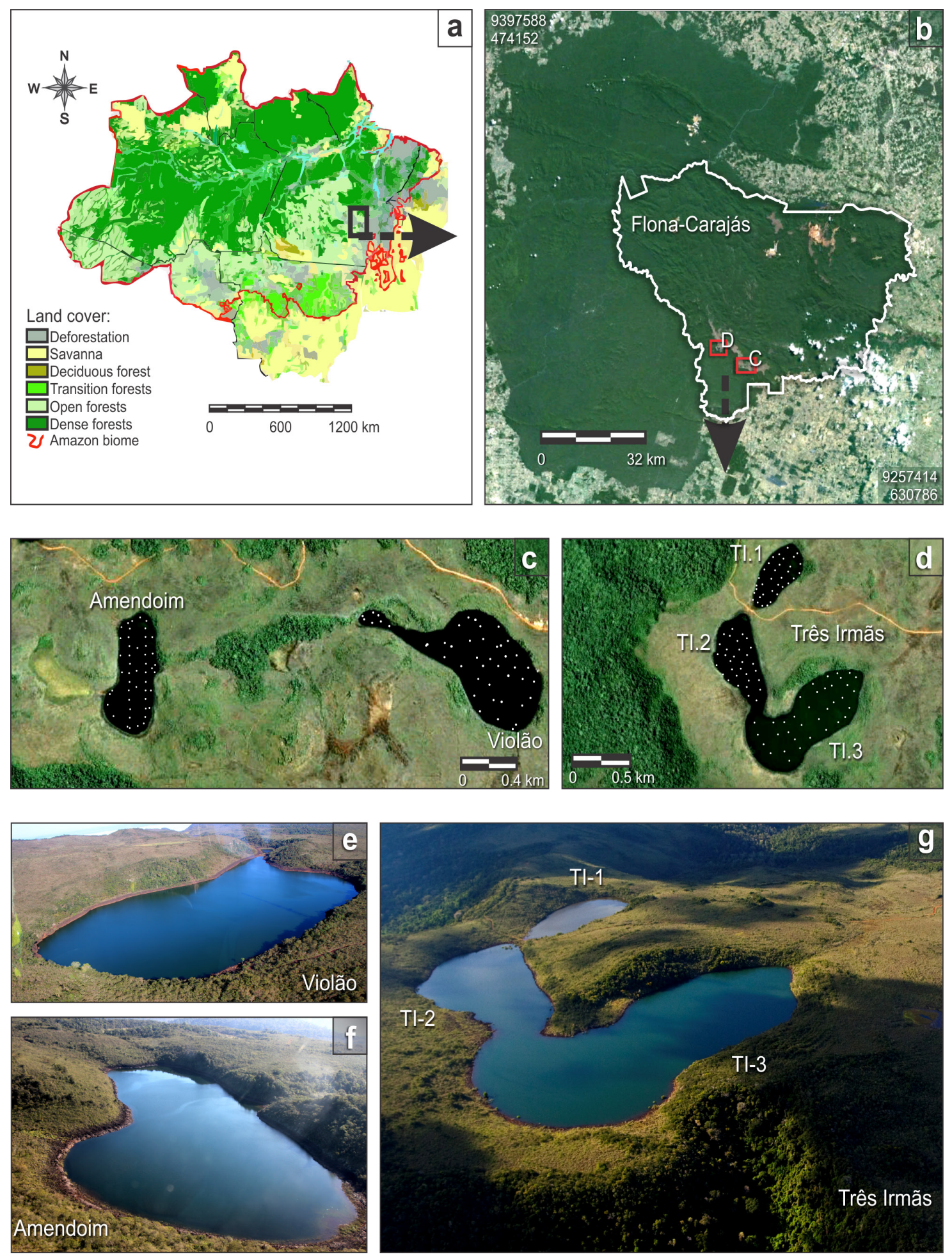

Figure 1 - a) Location map of the study site in the southeastern Amazon region (Imazon 2003) with a detail to b) Carajás National Forest (Flona-Carajás, Landsat image) and a detail to Serra Sul de Carajás and studied lakes; c) WorldView images of the Violão and Amendoim and d) Três Irmãs lakes in the eastern and western portion of the Serra Sul; sediment samples are represented by white dots; e) Aerial photography of the Violão, f) Amendoim and g) Três Irmãs lakes. 
water availability. Open forest and forest copse associated to "capão florestal" can also be observed in central portions of the plateau over degraded crusts (Guimarães et al. 2014, 2017). The Três Irmãs system presents surface connection between the three lakes.

The regional climate is tropical monsoon, with a mean annual temperature of $\sim 26^{\circ} \mathrm{C}$ (Alvares et al. 2014). Total annual precipitation ranges from 1420 to $2160 \mathrm{~mm}$, with a total mean of $\sim 1450 \mathrm{~mm}$ during the rainy season (November to May) and $235 \mathrm{~mm}$ during the dry season (June to October). In addition, around $80 \%$ of the total annual occur between December to May (Silva Júnior et al. 2017). The pattern of wind velocity and direction in the Serra Sul de Carajás shows slightly higher ranges of wind velocity $(\sim 3-4 \mathrm{~m} / \mathrm{s})$ with prevailing direction from NE and ENE (Guimarães et al. 2014).

\section{MATERIALS AND METHODS}

MORPHOLOGICAL SURVEY OF THE CATCHMENT BASINS

Worldview-2 multispectral satellite imagery with $2 \mathrm{~m}$ resolution were acquired in May 2013 for morphological mapping of the studied basins. A digital elevation model (DEM) was also developed using LiDAR (Light Detection and Ranging) data acquired in November 2009. The planimetric mapping was referenced to WGS 84 in UTM zone 22 south. The images were orthorectified and the resulting digital values were converted to terrain reflectance by the ATCOR algorithm using PCI Geomatica 13 (Geomatica Algorithm Reference 2003). This dataset was used for interpretation of the morphological features and real-time navigation during bathymetric surveys.

\section{MORPHOMETRIC SURVEY OF THE LAKES}

The bathymetric data were acquired using Raytheon DE719E and SyQuest PC 2010 echo sounders operating with a frequency of $200 \mathrm{kHz}$. The integrated acquisition of bathymetric data, with Differential Global Positioning System (DGPS, model Trimble AG-132 and SPS551, with differential correction from the OmniSTAR satellite ASAT L1 band) was carried out based on Hypack $6.2 \mathrm{~b}$ software. The digital files were stored in *raw and *xyz extension as follow: GGA (coordinate/s), VTG (velocity and direction/s) and DBS (depth/0.1s). The bathymetric maps were produced from 567,777 sampling points in a total of $89.6 \mathrm{~km}$ of bathymetric lines (Table I). The points were interpolated using Kriging geostatistical method in Surfer 11 software (Golden Software 2013). The bathymetric map and digital terrain model were designed for planimetric map with $1 \mathrm{~m}$ isobaths of interval. The integration of bathymetric data with LiDAR topography allowed a 3D visualization of the bottom lake morphology and adjacent catchment areas of the studied lakes. Morphometric parameters including size, form and special factors were calculated to the maximum lake levels according to Håkanson (2004) (Table II). The normalized parameters were statically evaluated by multivariate exploratory techniques including factor and cluster analysis using Statistica 8 (STATSOFT Inc. 2009). The main limnological data of the studied lakes are directly related to primary productivity, trophic state and sedimentary process (temperature, dissolved oxygen-DO, total organic carbon-TOC; total iron-Fe ${ }_{(t)}$, dissolved aluminium-Al ${ }_{(\mathrm{d})}$, chlorophyll-a-Chl-a, total nitrogen-TN, total phosphorous-TP, Secchi depthSD and lithological types) available in Sahoo et al. (2017), and morphometric parameters were also statistically evaluated by factor analysis, after raw data normalization.

\section{SEDIMENTOLOGICAL SURVEY OF THE LAKES}

Around 120 surficial $(0-10 \mathrm{~cm})$ sediment samples were collected using a Van Veen Grab sampler 
(Figure 1c, d), with geographical coordinates obtained from the DGPS. The sampling points were chosen based on the bathymetric maps of the lakes. These samples were described following Schnurrenberger et al. (2003).

\section{RESULTS}

\section{MORPHOLOGY AND MORPHOMETRY OF THE CATCHMENTS AND CENTRAL BASINS}

The catchment basin of Violão Lake presents the largest area $\left(1.83 \mathrm{~km}^{2}\right)$ and altitude variability (164 $\mathrm{m})$, while Três Irmãs system that may present surface connection between its three lakes during the rainy seasons (Figure 2a, b) shows the largest perimeter $(8.13 \mathrm{~km})$, but the lowest altitude variability $(77.5$ $\mathrm{m})$. Amendoim Lake has the smallest perimeter and surface area among the studied lakes (Table III). The catchments of these lakes present relatively high declivities $\left(>20^{\circ}\right.$ and maximum of $\sim 60^{\circ}$ ), with steep slopes covered by montane savanna. Slopes with ravines with capão florestal only occur in the catchment of the Violão and Amendoim lakes (Figure 2a). However, patches of forest in the Violão catchment occur over mafic sills. Several caves with guano can also be observed in this area, as well as guano over iron crust in the northwestern border near the patches of forest. The topographic profiles are illustrated in Figure 2c. Violão and Amendoim lakes are separated by an intermediate

TABLE I

Sampling points and lines generated during the bathymetric surveys of the studied lakes.

\begin{tabular}{ccc}
\hline Lakes & Sampling points & $\begin{array}{c}\text { Bathymetric lines } \\
(\mathbf{k m})\end{array}$ \\
\hline Violão & 107388 & 29 \\
Amendoim & 129438 & 27.4 \\
Três Irmãs & & \\
TI-1 & 44383 & 6.4 \\
TI-2 & 56917 & 9.9 \\
TI-3 & 229651 & 16.8 \\
Total & 567777 & 89.6 \\
\hline
\end{tabular}

basin that prevents any surface connection of water among them. The catchment of Amendoim Lake was composed by two active lakes (Figure 2a, c, see section 7-8), but the smaller one located in the western portion was progressively filled by detritic and organic sediments, and nowadays represents a swamp colonized by macrophytes (Guimarães et al. 2017). Once the three lakes of Três Irmãs are connected, the water flow follows the elevation gradient from TI-1 to TI-3 (Figure 2b, c, see section 1-2), forming a small waterfall between them. Patches of forest or open ombrophylous forest, over aluminous crust of likely volcanic origin, are also present in the catchment of the TI-1 and TI-3.

Considering the morphology of the central basins (Figure 3), Violão Lake has an NE-SW elongated guitar-shaped form and washing basin morphology marked by a steep margin, scoured in lateritic outcrops, and flat bottom. Its western portion presents a flat, shallow $(<2.5 \mathrm{~m}$ depth) and ellipsoidal area $(200 \times 100 \mathrm{~m})$ associated to embedded drainage (Souza Filho et al. 2016). This portion is linked by a narrow and elongated channel in NW-SE direction, and connects shallower and deeper zones. Fan morphology can be observed between these zones and in the southeastern portion of the lake (Figure 3). Amendoim Lake has a N-S elongated peanut form, steep margin and relatively flat bottom. Its bottom is colonized by macrophytes (Guimarães et al. 2017). The lake depocenter is located in the southern portion, where a structural high also occur. In addition, fan morphology is present in the southwestern and eastern portion. Differential position of the depocenter can also be observed in the TI-1 and TI-2 lakes of Três Irmãs system, which are located in the northeastern and western portion, respectively (Figure 3 ). Três Irmãs system has elongated form, and steep and smooth margins near the connection between lakes. The western margins of the TI-3 Lake are also smooth.

Based on the morphometric parameters (Tables II, III and IV), the Violão and TI-3 lakes have the highest values of $\mathrm{L}_{\max }, \mathrm{B}_{\max }, \mathrm{D}_{\max }, \mathrm{D}_{\text {mv }}$, 
a)

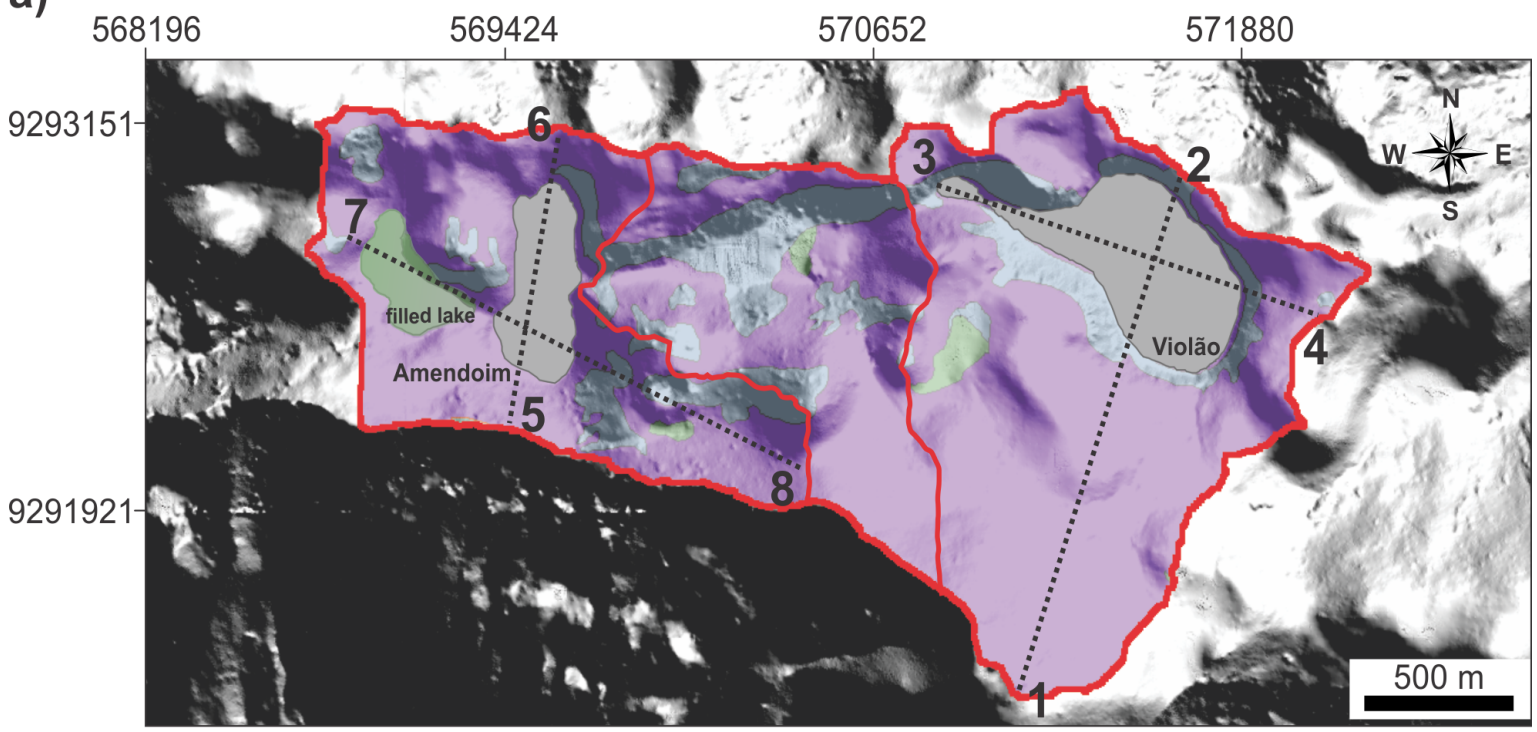

b) $\quad 560215 \quad 561442$

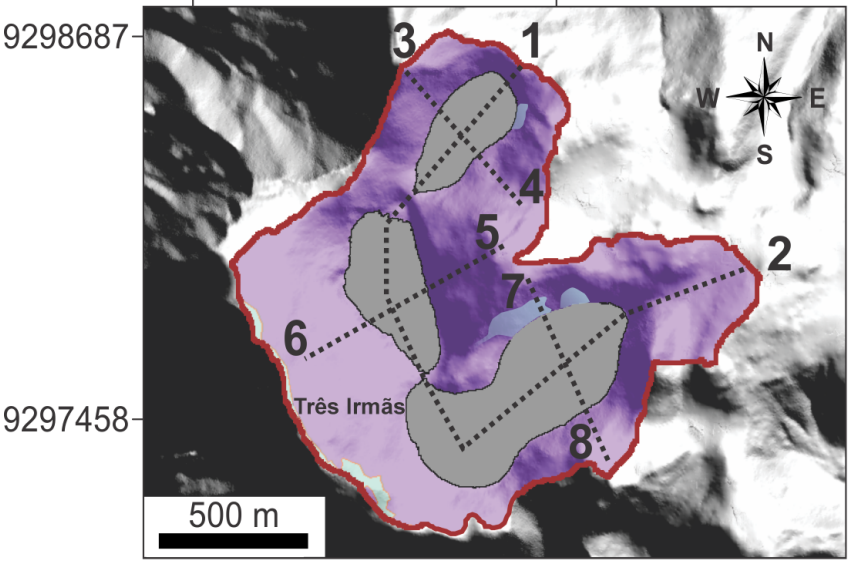

Depression on poorly drained grass field

Slopes with montane savanna

Slopes with ravines and forest

Dissected slopes or scarps

Lake

$\sim$ Boundary of the catchment

c)
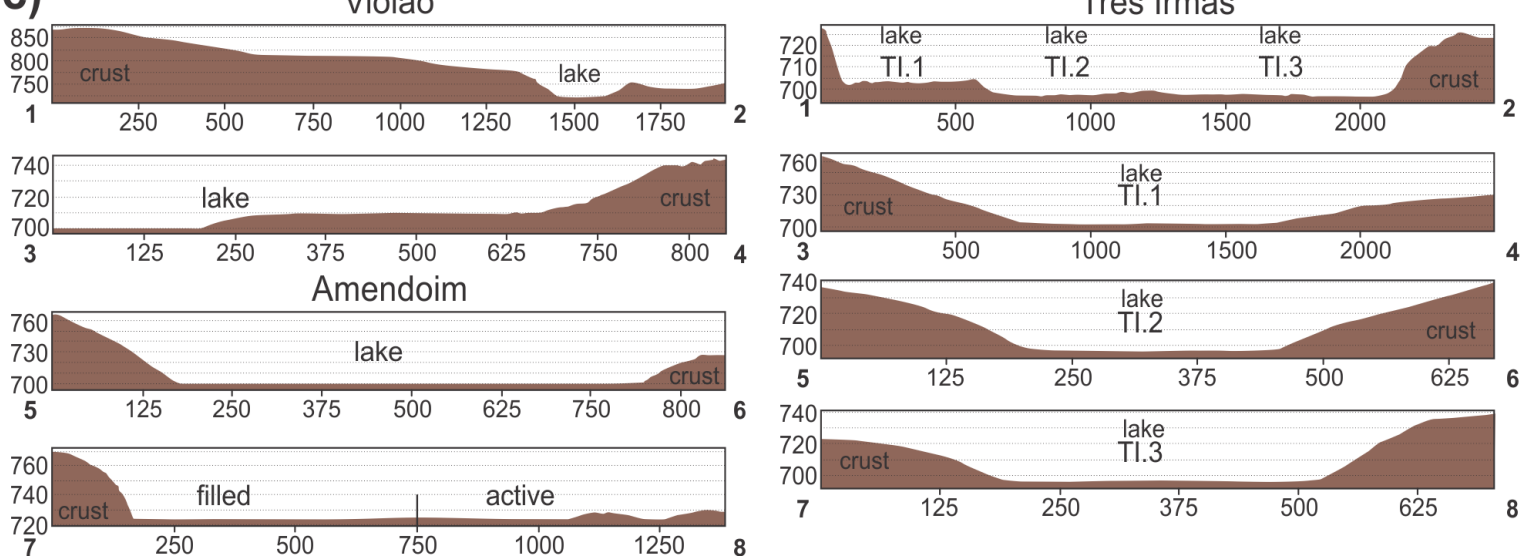

Figure 2 - Geomorphological maps of the catchment basins of the a) Violão, Amendoim and b) Três Irmãs lakes according Rezende and Barbosa (1972), and Golder (2010), with c) topographic sections of each basin; altitude and distance units are in meters. 
TABLE II

Morphometric parameters calculated according Håkanson (2004).

\begin{tabular}{|c|c|c|c|c|}
\hline Type & Parameter & Code & Unit & Description \\
\hline \multirow{7}{*}{ Length measures } & Maximum length & $\mathrm{L}_{\max }$ & $\mathrm{km}$ & $\begin{array}{l}\text { Line connecting the two most remote points on the } \\
\text { shoreline. } \\
\text { The straight line at the right angle to maximum length }\end{array}$ \\
\hline & Maximum width & $\mathrm{B}_{\max }$ & $\mathrm{km}$ & $\begin{array}{c}\left(\mathrm{L}_{\max }\right) \text { that connects the two most remote extremities on the } \\
\text { shoreline without crossing land. }\end{array}$ \\
\hline & Maximum depth & $\mathrm{D}_{\max }$ & $\mathrm{m}$ & Greatest known depth in the lakes. \\
\hline & Mean depth & $\mathrm{D}_{\mathrm{mv}}$ & $\mathrm{m}$ & Ratio between the lake volume (V) and the lake area (A). \\
\hline & Median depth & $\mathrm{D}_{50}$ & $\mathrm{~m}$ & $\begin{array}{c}\text { Consists in the depth value covering } 50 \% \text { of the cumulated } \\
\text { area of the lake. }\end{array}$ \\
\hline & Quartile depths & $\mathrm{D}_{25}-\mathrm{D}_{75}$ & $\mathrm{~m}$ & $\begin{array}{l}\text { Consists in the depth value covering } 25 \% \text { and } 75 \% \text { of the } \\
\text { cumulated area of the lake. }\end{array}$ \\
\hline & Shoreline length & $\mathrm{L}_{0}$ & $\mathrm{~km}$ & It may be estimated in geoprocessing software. \\
\hline \multirow{2}{*}{$\begin{array}{l}\text { Measures of area } \\
\text { and volume }\end{array}$} & Area & A & $\mathrm{km}^{2}$ & $\begin{array}{l}\text { It may be calculated by the satellite image interpretation, } \\
\text { thus each point in the shoreline is a geographic coordinate. }\end{array}$ \\
\hline & Volume & $\mathrm{V}$ & $\mathrm{m}^{3}$ & $\begin{array}{c}\text { It is based on the linear and parabolic approximation of the } \\
\text { volume. }\end{array}$ \\
\hline \multirow{10}{*}{$\begin{array}{l}\text { Special measures } \\
\text { and measures of } \\
\text { form }\end{array}$} & Relative depth & $\mathrm{D}_{\text {rel }}$ & $\mathrm{m}$ & $\begin{array}{c}\text { Ratio between the maximum depth }\left(\mathrm{D}_{\max }\right) \text { and mean } \\
\text { diameter of the lake. }\end{array}$ \\
\hline & Shore development & $\mathrm{L}_{\mathrm{d}}$ & $*$ & $\begin{array}{l}\text { Ratio between the shoreline and a perfect circle with area } \\
\text { equal to the lake, used to measure the shoreline irregularity. }\end{array}$ \\
\hline & Morphometric index & MI & $*$ & $\begin{array}{l}\text { It gives the relationship between the shoreline lenght }\left(\mathrm{L}_{0}\right) \\
\text { and the mean depth }\left(\mathrm{D}_{\mathrm{mv}}\right) \text {. }\end{array}$ \\
\hline & $\begin{array}{c}\text { Volume } \\
\text { development }\end{array}$ & $V_{d}$ & $*$ & $\begin{array}{l}\text { Ratio between the water volume }(\mathrm{V}) \text { and the volume of a } \\
\text { cone, with the base equal to the water surface area }(\mathrm{A}) \text { and } \\
\text { with a height equal to the maximum depth }\left(\mathrm{D}_{\max }\right) \text {. }\end{array}$ \\
\hline & Dynamic ratio & DR & $*$ & $\begin{array}{l}\mathrm{DR} \text { is a standard morphometric parameter in contexts of } \\
\text { lake resuspension based area (A) and mean depth }\left(\mathrm{D}_{\mathrm{mv}}\right) \text {. }\end{array}$ \\
\hline & $\begin{array}{l}\text { Energy-topography } \\
\text { factor }\end{array}$ & ET & $*$ & $\begin{array}{l}\text { It represents the fraction of the lake bed where resuspension } \\
\text { is likely to appear, which is dependent of DR. }\end{array}$ \\
\hline & $\begin{array}{l}\text { Depth of the wave } \\
\text { base }\end{array}$ & $\mathrm{D}_{\mathrm{wb}}$ & $\mathrm{m}$ & $\begin{array}{l}\text { Depth separating transportation area (with resuspension) } \\
\text { from accumulation area (without resuspension). }\end{array}$ \\
\hline & $\begin{array}{l}\text { Lake bottom } \\
\text { roughness }\end{array}$ & Ro & $*$ & It measures the degree of irregularity of the lake bottom. \\
\hline & $\begin{array}{l}\text { Hypsographic and } \\
\text { volume curves }\end{array}$ & - & $\%$ & $\begin{array}{l}\text { It illustrates a depth-area (hypsographic) and depth-volume } \\
\text { (volume) curve. }\end{array}$ \\
\hline & Mean slope & $\mathrm{S}_{\mathrm{mv}}$ & $\%$ & Mean slope for all lake in $\%$ terms. \\
\hline
\end{tabular}

* dimensionless.

$\mathrm{D}_{50}, \mathrm{D}_{25}, \mathrm{D}_{75}, \mathrm{~L}_{0}, \mathrm{~A}, \mathrm{~V}, \mathrm{D}_{\text {rel }}, \mathrm{L}_{\mathrm{d}}, \mathrm{D}_{\mathrm{wb}}$ and $\mathrm{S}_{\mathrm{mv}}$, while TI-2 lake shows the lowest values of $\mathrm{D}_{\text {max }}, \mathrm{D}_{\mathrm{mv}}$, $\mathrm{D}_{50}, \mathrm{D}_{25}, \mathrm{D}_{75}, \mathrm{~V}, \mathrm{D}_{\text {rel }}, \mathrm{V}_{\mathrm{d}}, \mathrm{L}_{\mathrm{d}}$ and $\mathrm{S}_{\mathrm{mv}}$, and highest MI. Although TI-1 Lake presents the lowest values of $\mathrm{L}_{\max }, \mathrm{B}_{\max }, \mathrm{L}_{0}, \mathrm{~A}$ and $\mathrm{D}_{\mathrm{wb}}$, it has the highest $\mathrm{V}_{\mathrm{d}}$ among the studied lakes. Ro has maximum and minimum values for Amendoim and Violão lakes, respectively. This is clearly observed in the multivariate analysis of these data (Figure $4 a, b)$. Two important principal components (PC) could be defined with Eigen values $>1$, which explained $\sim 88 \%$ of the total variance of the dataset where PC1 and PC2 account $73 \%$ and $15 \%$ of the total variance, respectively. Violão and TI-3 lakes are clustered together (Figure 4a) based on the highest values of the morphometric parameters of groups 
TABLE III

Quantitative characteristics of the catchment basins of Violão, Amendoim and Três Irmãs lakes.

\begin{tabular}{cccccc}
\hline Basin & Perimeter $(\mathbf{k m})$ & Area $\left(\mathbf{k m}^{\mathbf{2}}\right)$ & $\begin{array}{c}\text { Minimum } \\
\text { altitude } \mathbf{( m )}\end{array}$ & $\begin{array}{c}\text { Maximum altitude } \\
\mathbf{( m )}\end{array}$ & $\begin{array}{c}\text { Altitude } \\
\text { variability }(\mathbf{m})\end{array}$ \\
\hline Violão & 7.77 & 1.83 & 723.3 & 877.4 & 164.1 \\
Amendoim & 6.89 & 1.20 & 700.5 & 834.5 & 134.0 \\
Três Irmãs & 8.13 & 1.61 & 695.3 & 772.8 & 77.5 \\
\hline
\end{tabular}
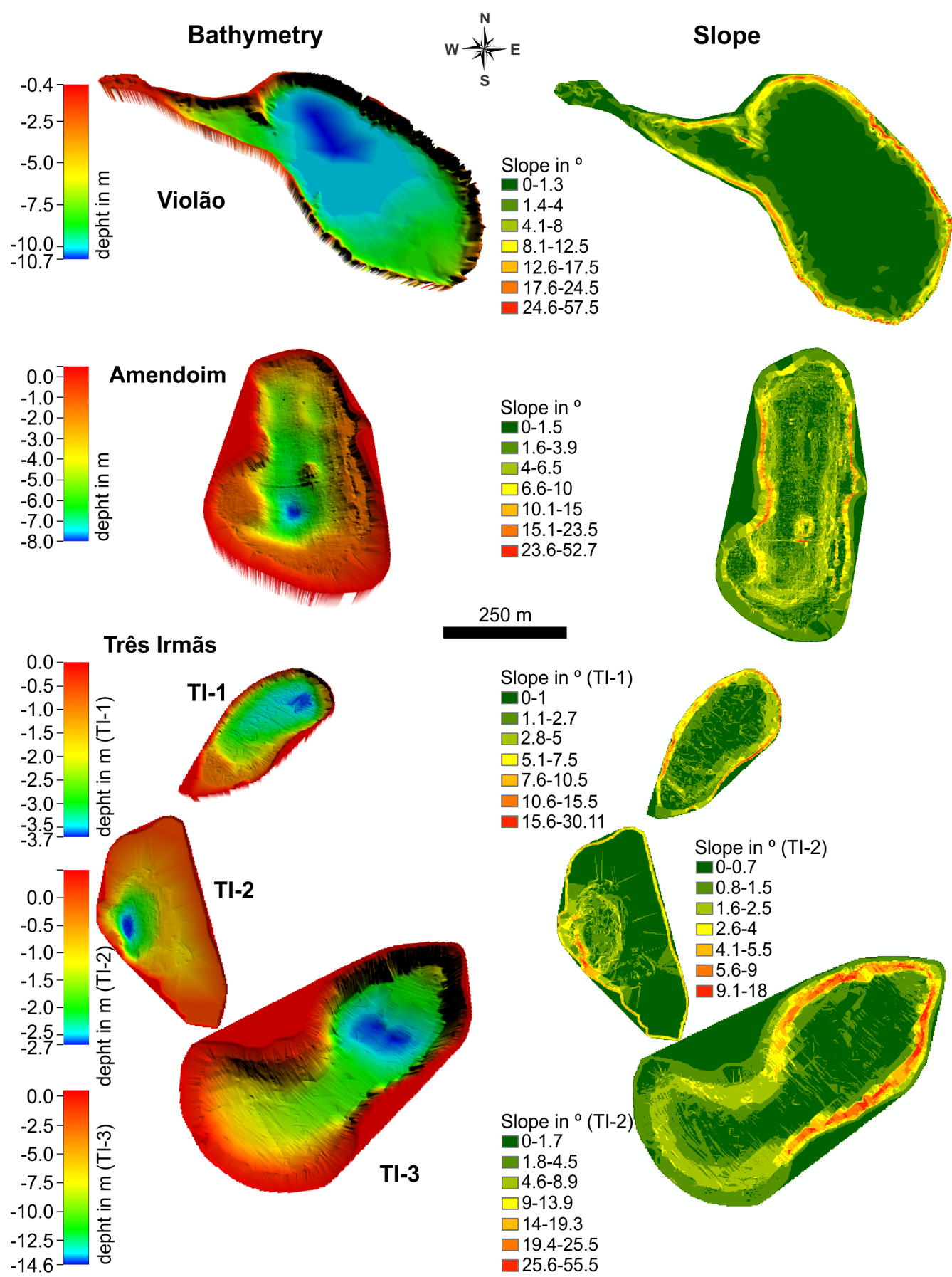

Figure 3 - Bathymetric and slope map of the Violão, Amendoim and Três Irmãs lakes. 


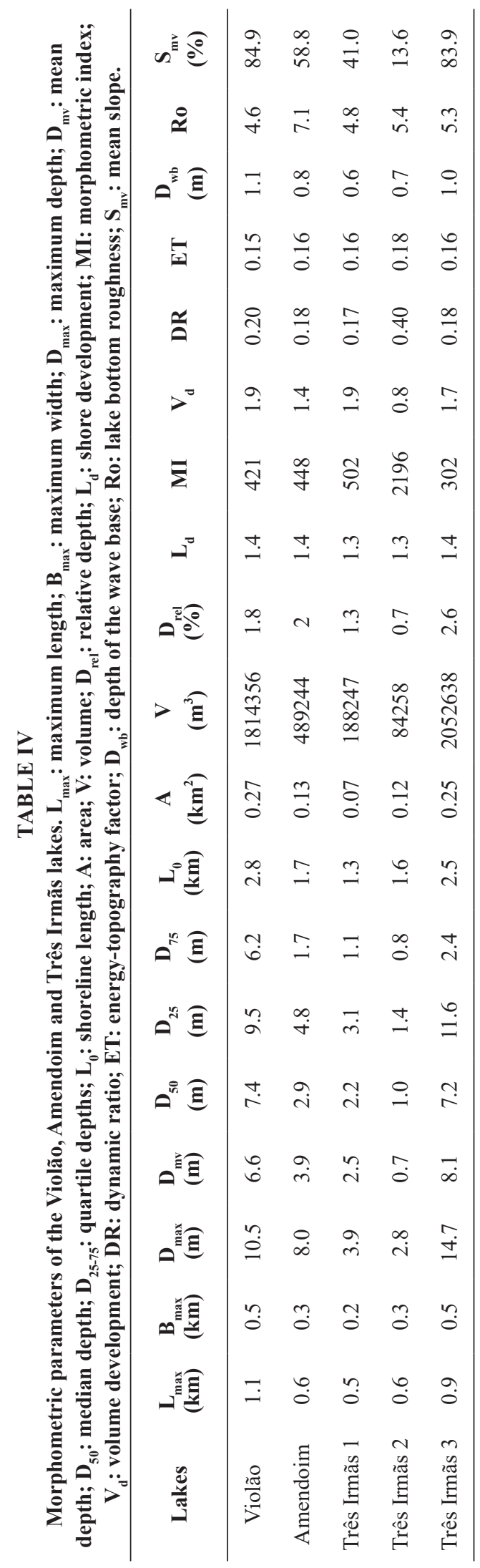

2 (positive loadings on factor 1 and 2; Figure 4b). Amendoim and TI-1 lakes are clustered due to moderate values of the parameters of group 2. TI-2 Lake is isolated from other lakes (Figure 4a), which is related to the lowest value of the parameter of groups 1 (lowest loadings on factor 1) and highest value of group 3 (negative loadings on factor 1and 2) (Figure $4 b$ ).

The hypsographic and volume curves show that half of the total areas and volumes of Amendoim, TI- 1 and TI-2 lakes are located around $\mathrm{D}_{\mathrm{mv}}$ and $\mathrm{D}_{50}$. Half of the total area and volume of Violão Lake are observed at $9 \mathrm{~m}$ and $4 \mathrm{~m}$, respectively, and at 5 and $8 \mathrm{~m}$, respectively for TI-3 Lake (Table SI Supplementary Material; Figure 4c, d).

The relationship between limnological and morphometric data (Tables IV and V) allowed to identify two important principal components with Eigen values $>1$, which explain $\sim 80 \%$ of the total variance of the dataset. The first principal component (PC1) represents 55\% and the second one accounts $25 \%$ of the total variance. Thus, TOC, $\mathrm{TN}, \mathrm{Chl}-\mathrm{a}, \mathrm{pH}, \mathrm{TP}, \mathrm{Fe}_{(\mathrm{t})}, \mathrm{Al}_{\text {(d) }}$ are well-correlated with lithological types (group 1; highly positive loading on factor 2). DO and temperature are grouped with MI, DR, ET (group 2; highly negative loadings on factor 1), while $S D$ is positively correlated with $\mathrm{V}_{\mathrm{d}}$, $\mathrm{L}_{\mathrm{d}}, \mathrm{L}_{0}, \mathrm{~A}, \mathrm{~V}, \mathrm{D}_{\text {mv }}, \mathrm{D}_{\text {max }}, \mathrm{D}_{\text {rel }}, \mathrm{D}_{50}, \mathrm{D}_{25}, \mathrm{D}_{75}, \mathrm{D}_{\mathrm{wb}}$ and $\mathrm{S}_{\mathrm{mv}}$ (group 3; highly positive loadings on factor 1). Ro did not present significant relationship with studied morphometric parameters. Its highest values are found in Amendoim Lake (Figure 4e).

\section{SURFACE SEDIMENTARY COVER}

The margins and shallower portions of Violão Lake are represented by lateritic crust and fragmental peat, respectively (Figure 5). The latter is also occurred at depths of $\sim 9 \mathrm{~m}$ and near the fan morphologies observed in the morphological analysis. Organic mud occurs in the transition between fragmental peat and slightly oxidized mud that cover most of the central portion of the 


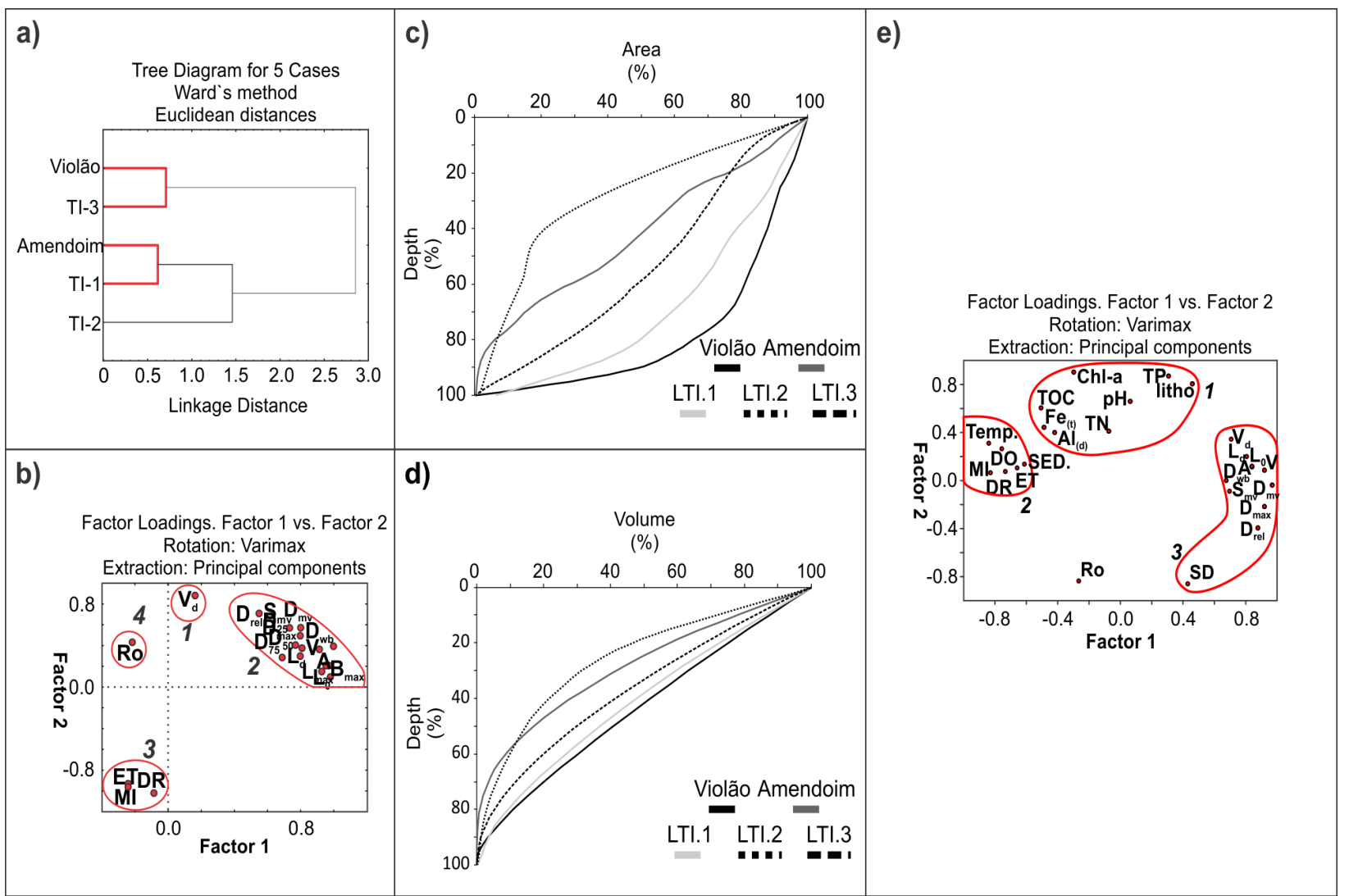

Figure 4 - Statistical analysis of morphometric parameters of the studied lakes according to a) similarities between lakes by cluster analysis, and b) relationship between parameters by factor analysis; $\mathrm{B}_{\max }$ : maximum width; $\mathrm{D}_{\max }$ : maximum depth; $\mathrm{D}_{\operatorname{mv}}$ : mean depth; $\mathrm{D}_{50}$ : median depth; $\mathrm{D}_{25-75}:$ quartile depths; $\mathrm{L}_{0}$ : shoreline length; $\mathrm{A}$ : area; V: volume; $\mathrm{D}_{\text {rel }}:$ relative depth; $\mathrm{L}_{\mathrm{d}}$ : shore development; MI: morphometric index; $\mathrm{V}_{\mathrm{d}}$ : volume development; DR: dynamic ratio; ET: energy-topography factor; $\mathrm{D}_{\mathrm{wb}}$ : depth of the wave base; Ro: lake bottom roughness; $\mathrm{S}_{\mathrm{mv}}$ : mean slope; c) Hypsographic and d) volume curves considering cumulative areas, volumes and depths of the studied lakes; e) Relationship between limnology and morphological and morphometric parameters of the lakes by factor analysis; $\mathrm{D}_{\max }$ : maximum depth; $\mathrm{D}_{\text {mv }}$ : mean depth; $\mathrm{L}_{0}$ : shoreline length; $\mathrm{A}$ : area; $\mathrm{V}$ : volume; $\mathrm{D}_{\text {rel }}:$ relative depth; $\mathrm{L}_{\mathrm{d}}$ : shore development; MI: morphometric index; $\mathrm{V}_{\mathrm{d}}$ : volume development; DR: dynamic ratio; Temp: temperature; DO: dissolved oxygen; TOC: total organic carbon; $\mathrm{Fe}_{(\mathrm{t})}$ : total iron; $\mathrm{Al}_{(\mathrm{d})}$ : dissolved aluminium; Chl-a: chlorophyll-a; TN: total nitrogen; TP: total phosphorous; litho: lithological types; SD: Secchi depth.

lake. Mud locally occurs near the outflows of the main drainages. The bottom of Amendoim Lake is mainly represented by organic mud, while mud occurs preferentially near the outflows of the main drainages. Fragmental peat is restricted to the central and deeper portions of this lake. The Três Irmãs system presents lateritic crusts in the margins of the TI-1 and TI-3 lakes, while fragmental peats are predominant in TI-2 Lake, and secondarily in the margins of the TI- 1 and TI- 3 lakes bordering the lateritic crust. Organic mud occurs in the central portion of the lakes, and in the western portion of the TI-3 Lake (Figure 5).

\section{DISCUSSION}

\section{LAKE MORPHOTYPES}

Lakes may present variable form related to their formation and evolution, which are dependent of interactions with environments and climate conditions (Timms 1992). A precise understanding of lake form and function is required to the well interpretation of quantitative morphometric 


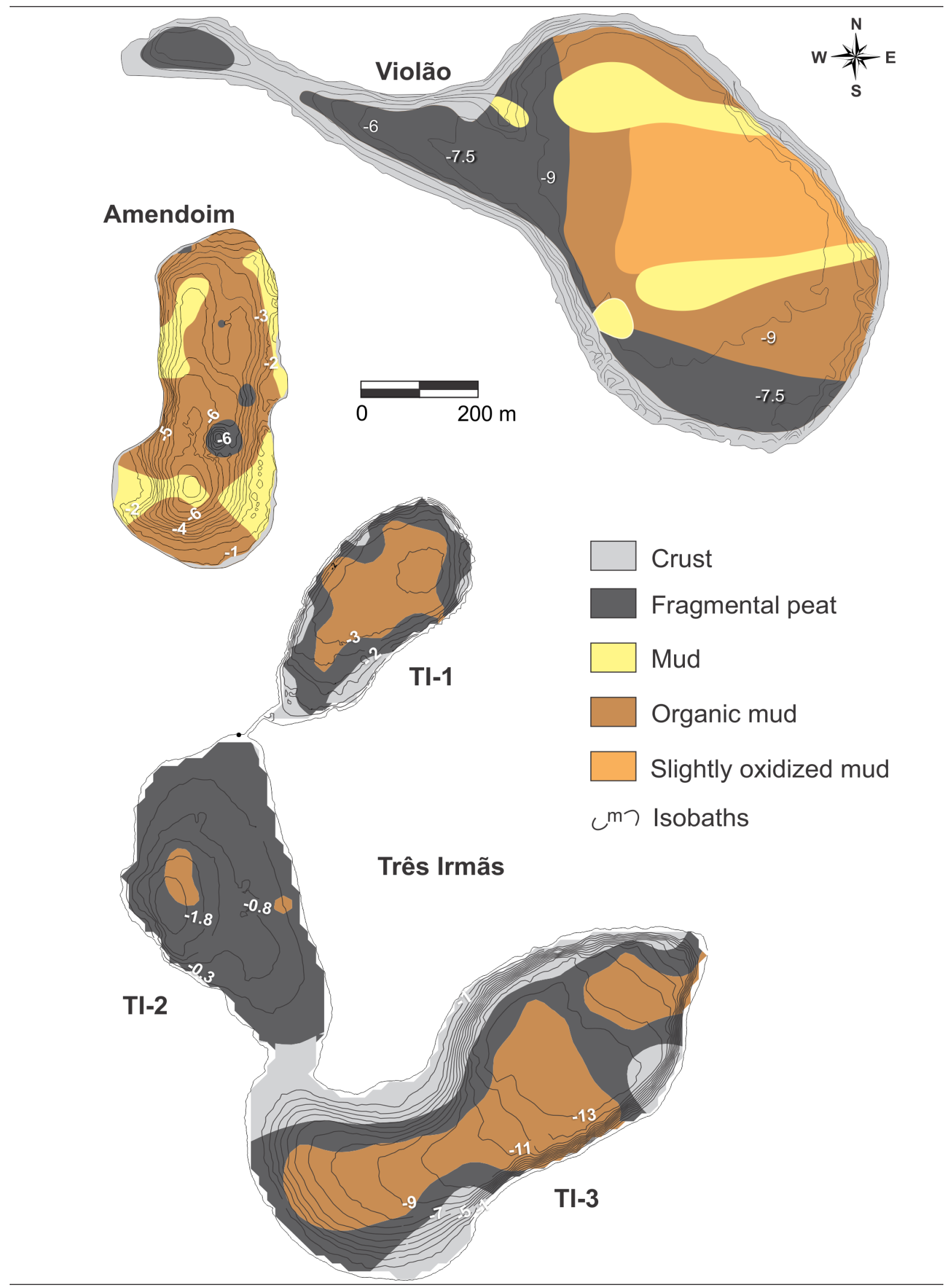

Figure 5 - Sedimentological map of the Violão, Amendoim and Três Irmãs lakes. 


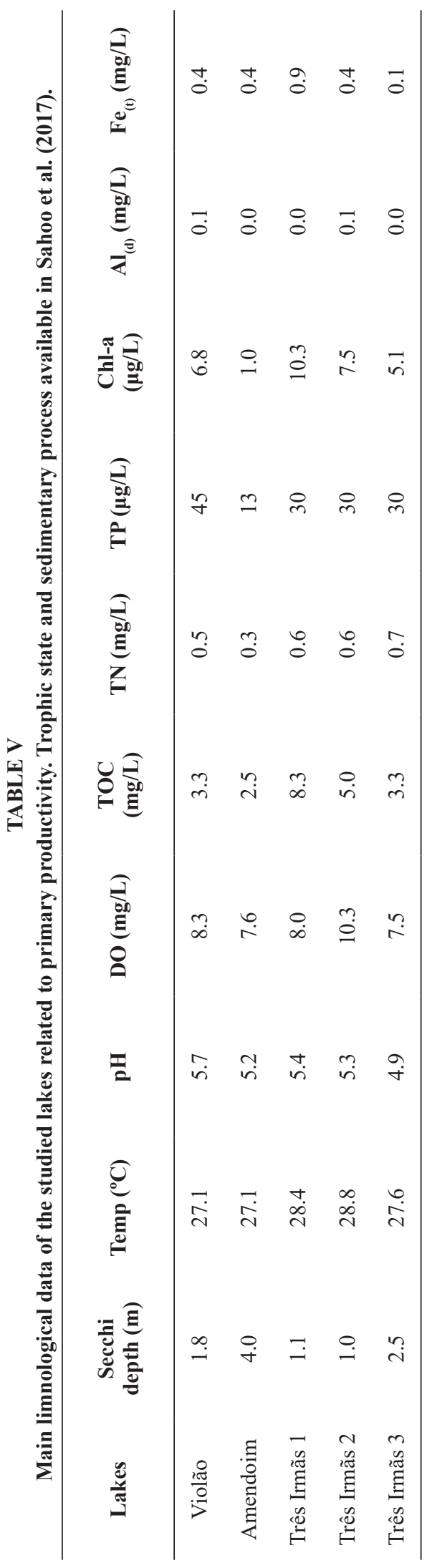

attributes such as size, form and special factors (Håkanson 2004).

The studied lakes may be classified as midaltitude, very small and shallow according to their elevation (above mean sea-level), catchment and central basin areas, and mean depth, respectively (Buraschi et al. 2005, Sahoo et al. 2017).

The Violão and TI-3 lakes with the highest $\mathrm{L}_{\max }$, $\mathrm{B}_{\text {max }}$ and $\mathrm{D}_{\text {max }}$ may present large vertical movements of the water due to wind action (Fantim-Cruz et al. 2008). As depth is closely related to $\mathrm{V}$, as well as $\mathrm{V}$ with $\mathrm{A}$, the high values of these parameters in the Violão and TI-3 lakes as well as their flattened volume curves may indicate restricted solar penetration with stratified waters. However, maximum temperature difference between the surface and bottom water of the studied lakes are very weak (not $>1.5^{\circ} \mathrm{C}$ ), which indicates weakly stratified waters (Souza Filho et al. 2016, Sahoo et al. 2017). This may be caused by a number of mechanisms, including wind-induced turbulence, high precipitation, and convention mixing might mix the water, resulting in a smaller range of water temperature. On the other hand, TI-2 showed the lowest values of depth and V, likely allowing the activity of autotroph organisms (Morais et al. 2005).

$\mathrm{D}_{\text {rel }} \leq 5 \%$ may suggest complete circulation of lake waters under the presence of relatively strong winds, which allow interchanges between water and bottom surface (Sperling 1999). This is particularly true for lakes with the main axis oriented to the main wind direction (Panosso et al. 1995). In the study site, Violão, TI-1 and TI-3 may be more influenced by winds, since theirs prevailing directions are from NE and ENE (Guimarães et al. 2014). In addition, margins of the Três Irmãs system are smoother and may be more sensible to wind action. However, wind velocities in the studied area are around 3 to $4 \mathrm{~m} / \mathrm{s}$, which only produce gentle breeze under such velocities 
according to the Beuafort scale (e.g. Saucier 1955), and it may not influence bottom sediment.

Very shallow $\mathrm{D}_{\mathrm{wb}}$ of Violão, Amendoim, TI-1 and TI-3 lakes, considering $\mathrm{D}_{\max }, \mathrm{D}_{\mathrm{mv}}$ and $\mathrm{D}_{50}$, are indicative of extensive accumulation areas with restricted areas of physical erosion (e.g. Håkanson 2004). In opposition, TI-2 Lake with similar values of $\mathrm{D}_{\mathrm{wb}}, \mathrm{D}_{\mathrm{mv}}$ and $\mathrm{D}_{50}$ may be more sensible to erosive process.

$\mathrm{V}_{\mathrm{d}}$ values indicated that all lakes presented concave basins ( $\mathrm{V}_{\mathrm{d}}$ : 1.33-2.00; Håkanson 1981), except for TI-2 Lake. This latter has slightly convex basin $\left(\mathrm{V}_{\mathrm{d}}\right.$ : 0.67-1.00; Håkanson 1981), thus more influenced by sedimentation and erosion process (Håkanson 1981, Barbanti 1985). The lowest depths of this lake and its hypsographic curve reinforced this interpretation.

The highest MI was found in TI-2 Lake, since it has lower $\mathrm{D}_{\mathrm{mv}}$ and moderate value of $\mathrm{L}_{0}$, which indicates that the lake occupies a relatively large area, but it is very shallow and may be highly influenced by hydrodynamic processes.

DR and ET values indicate wind-wave influence on lake bottom and bottom resuspension with DR higher than 3.8. Furthermore, DR of 0.25 suggests that most of the lakes have at least $15 \%$ of ET areas (Håkanson and Jansson 1983). However, only TI-2 Lake presented significantly higher DR, which indicates an increased percentage of ET areas.

Considering the surface sedimentary cover, relation of morphometric parameters described above with sedimentological process, it is evident that bottom sediment of all lakes are deposited under very low energy conditions of waters (i.e. suspension process) and they are less influenced by post-depositional processes. This is supported by the geochemical study carried out in Carajás lakes by Sahoo et al. $(2015,2016 b)$, where the heavy minerals mainly Si (detrital), Ti and Zr were distributed at the margin of the lake and decreases their concentrations towards the center of the lake.
Low energy flow leads to sorting effect of heavy minerals according to the hydraulic properties and low depositional process (Cingolani et al. 2003). Similarly, despite having high enrichment of $\mathrm{Fe}$ and organic matter, the association of trace and REEs with Al-clays in those lake sediments indicates less influence of depositional and post-depositional process (including the erosion and resuspension process) on elemental chemistry (Sahoo et al. 2015, 2016b).

According to the model of trophic classification based on $\mathrm{D}_{\text {mv }}$ (Thienemann 1927, Cole 1975), the studied lakes may be grouped as eutrophic (depths $<18 \mathrm{~m}$ ), with relatively high nutrient availability and euphotic zone. However, trophic conditions may primarily consider geoenvironmental characteristics of the catchment basins such as lithology, soils and vegetation types (Lane et al. 2007). In such case, nutrient input in the Amendoim Lake is significantly low due to catchment lithology, mainly represented by iron-rich crusts, resulting in oligotrophic to ultra-oligotrophic conditions (Sahoo et al. 2016a).

$\mathrm{L}_{\mathrm{d}}>3$ may be indicative of well-developed shore communities less vulnerable to eutrophication (Håkanson 1981), but it is not the case of the studied lakes classified as highly vulnerable $\left(\mathrm{L}_{\mathrm{d}}\right.$ from 1.3 to 1.5; Table IV). However, this classification must be viewed with care, since Amendoim Lake is oligotrophic to ultra-oligotrophic (Sahoo et al. 2016a). Thus, it is more suitable the use of $L_{d}$ as a direct proportion of $\mathrm{L}_{0}$ and $\mathrm{A}$, as well as higher values may be applied to describe more elongated lake forms (Wetzel 2001). $\mathrm{L}_{\mathrm{d}}$ may also be used to indicate the origin of lakes (Hutchinson 1957, Timms 1992). Therefore, the studied lakes were classified as circular to subcircular. In addition, these lakes have very low degree of shoreline irregularity (Timms 1992), very similar with lakes formed by solution process (Hutchinson 1957). Additionally, very low $\mathrm{V}_{\mathrm{d}}$ values reinforced this interpretation (Wetzel 2001). 
High Ro of Amendoim Lake is directly related to the presence of a structural high in its southern portion. High $\mathrm{S}_{\mathrm{mv}}$ as observed for Violão and TI-3 lakes is indicative that both lakes present washing basin morphology (e.g. Souza Filho et al. 2016).

RELATIONSHIP BETWEEN GEOMORPHOLOGY AND LIMNOLOGY OF THE UPLAND LAKES

Morphology and morphometry may be considered as important attributes for controlling water quality (Moses et al. 2011, Stefanidis and Papastergiadou 2012) as well as trophic state of lakes (GenkaiKato and Carpenter 2005). As it is evident that, in general, shallow lakes are eutrophic and deep lakes are oligotrophic (Thienemann 1927), since the former usually have a greater productive, if they are not limited to light (Magyar et al. 2013). Shallow lakes present large dynamic of ecological conditions as all depths may be affected by sunlight. In addition, they may be holomictic (monomictic and polymictic) with short stable stages (Crisman et al. 2005).

Trophic state (TS) is an indication of a productivity and nutrition levels, which is calculated based on three key water quality parameters such as Chl-a, TP and SD following the modified Carlson index (TSi, Carlson 1977, Lamparelli 2004, Molisani et al. 2010). According to Sahoo et al. (2017), Violão, TI-1 and TI-2 lakes are mainly eutrophic, while Amendoim and TI-3 lakes are oligotrophic and mesotrophic, respectively. Based on the relationship between geomorphology and hydrochemistry of the studied lakes and trophic state variables, $\mathrm{TN}, \mathrm{pH}, \mathrm{Fe}_{(\mathrm{t})}$ and $\mathrm{Al}_{(\mathrm{d})}$ are mainly controlled by the catchment characteristics of the lakes, which included lithotypes, drainage system and vegetation types. TOC and TN may also have derived from organic matter of water-living organisms (e.g. Sahoo et al. 2015). Autotrophic organisms may develop in lake waters once organic and inorganic materials relatively enriched in nutrients are transported by surface runoff into the central basins. However, Amendoim Lake has poor-nutrient water, since its catchment basin is only represented by iron crust that is poor in nutrients and very resistant to chemical and physical weathering (e.g. Sahoo et al. 2015, 2016a, b). Also, its main drainage is related to a filled lake that acts as a nutrient filter. Therefore, sunlight may easily reaches the bottom sediments allowing the growth of macrophytes.

Lakes with great water volume may present high content of DO and consequently high capacity to assimilate organic components (Sperling 1999). However, MI and DR likely influence temperature and DO of waters of the TI-2 Lake (shallower), since it is the shallowest and hydrodynamically active lake of the studied site. Under this condition, lake water may be mixed by the wind allowing warming and oxygenation of the bottom (Sahoo et al. 2016a).

$\mathrm{SD}$ is a rapid way to evaluate the underwater light penetration by visual measure (Luhtala and Tolvanen 2013). Suspended particulate, dissolved matter (inorganic or organic) and chlorophyll along with other photosynthetic pigments of living phytoplankton attenuate light penetration in the water column of the lakes (Kirk 2011). Thus, SD may also indicate thickness of the photosynthetically active water layer (Preisendorfer 1986). In this work, SD represents a mixture of organic and inorganic components. $\mathrm{V}_{\mathrm{d}}, \mathrm{L}_{\mathrm{d}}, \mathrm{L}_{0}, \mathrm{~A}, \mathrm{~V}, \mathrm{D}_{\mathrm{mv}}, \mathrm{D}_{\text {max }}$ and $\mathrm{D}_{\text {rel }}$ are associated with horizontal and vertical measurements of the lakes, and well correlated to SD. Thus, larger and deeper lakes such as Violão and TI-3 have high transparency, while TI-2 has the lowest. Nevertheless, Amendoim Lake is relatively deep and has the highest water transparency among the studied lakes, but it is ultra-oligotrophic to oligotrophic (Sahoo et al. 2016a). 


\section{CONCLUSION}

The upland lakes Violão, Amendoim and Três Irmãs (TI-1, TI-2 and TI-3) are classified as midaltitude, very small and shallow based on elevation, catchment and central basin areas. Morphometric parameters related to length, area and volume suggest that Violão and TI-3 lakes may present large vertical movements of the water due to wind action and weakly stratified waters. Although, depth and shore development $\left(\mathrm{L}_{\mathrm{d}}\right)$ parameters are directly used to indicate trophic conditions, this may not be applicable for the present study, because the Amendoim Lake is relatively deep but oligotrophic to ultra-oligotrophic. The lakes are circular to subcircular and concave, likely formed by solution process. Convex central basin and highest dynamic ratio are only observed for TI-2 Lake, which suggest higher influence of hydrodynamic. Therefore, the bottom sediment of all lakes were deposited under very low energy conditions of waters (i.e. suspension process) and they are less influenced by post-depositional processes, except LTI-2 Lake. The relationship between geomorphological and limnological characteristics of the lakes, and temperature and dissolved oxygen of waters of the TI-2 Lake are may be associated with morphometric index and dynamic ration, since it is the shallowest and hydrodynamically active lake of the studied site. Nevertheless, lake water quality may be primarily influenced by lithotypes, soil availability, vegetation and drainage system of the catchment basins.

\section{ACKNOWLEDGMENTS}

We would like to acknowledge the financial support and field assistance provided by Vale Institute of Technology, Conselho Nacional de Desenvolvimento Científico e Tecnológico (CNPq - Prc. 479182/2012-4, 442088/2014-0) and Fundação Amazônia Paraense de Amparo à Pesquisa (FAPESPA - Proc. 355388/2014). The second (JTFG) and third (PWMSF) authors was supported by CNPq through research scholarship (302839/2016-0 and 306450/2013-5, respectively). The authors thank the members of DIPF, GELIF, DIST, LISF, LAMSF of Vale S.A. for the field support and scientific discussions. This project was carried out in the National Forest of Carajás under permission of IBAMA (SISBIO 35594-2).

\section{REFERENCES}

ALVARES CA, STAPE JL, SENTELHAS PC, GONÇALVES JLM AND SPAROVEK G. 2014. Köppen's climate classification map for Brazil. Meteorol Z 22: 711-728.

BARBANTI L. 1985. Some problems and new prospects on physical limnology: a review. Mem Ist Ital Idrobiol 43: $1-32$.

BEISNER BE, PERES PR, LINDSTROM ES, BARNETT A AND LONGHI ML. 2006. The role of environmental and spatial processes in structuring lake communities from bacteria to fish. Ecology 87(12): 2985-2991.

BRITO JG, ALVES LF AND ESPIRITO SANTO HMV. 2014. Seasonal and spatial variations in limnological conditions of a floodplain lake (Lake Catalão) connected to both the Solimões and Negro Rivers, Central Amazonia. Acta Amazon 44(1): 121-134.

BURASCHI E, SALERNO F, MONGUZZI C, BARBIERO G AND TARTARI G. 2005. Characterization of the Italian lake-type and identification of their reference site using anthropogenic pressure factors. J Limnol 64: 75-84.

CARLSON RE. 1977. Atrophic state index for lakes. Limnol Oceanogr 22: 361-369.

CINGOLANI CA, MANASSERO M AND ABRE P. 2003. Composition, provenance, and tectonic setting of Ordovician siliciclastic rocks in the San Rafael block: southern extension of the Precordillera crustal fragment, Argentina. J South Am Earth Sci 16: 91-106.

COLE GA. 1975. Textbook of Limnology. Mosby, p. 283.

CORDEIRO RC, TURCQ B, SIFEDDINE A, LACERDA LD, SILVA FILHO EV, GUEIROS B, POTTY YP, SANTELLI RE, PÁDUA EO AND PATCHINELAM SR. 2011. Biogeochemical indicators of environmental changes from $50 \mathrm{ka}$ to $10 \mathrm{ka}$ in a humid region of the Brazilian Amazon. Palaeogeogr Palaeoclimatol Palaeoecol 299: 426-436.

CRISMAN TL, MITRAKI C AND ZALIDIS G. 2005. Integrating vertical and horizontal approaches for management of shallow lakes and wetlands. Ecoll Eng 24(4): 379-389.

FANTIN-CRUZ I, LOVERDE-OLIVEIRA S AND GIRARD P. 2008. Caracterização morfométrica e suas implicações 
na limnologia de lagoas do Pantanal Norte. Acta Sci, Bio Sci 30(2): 133-140.

GENKAI-KATO M AND CARPENTER SR. 2005. Eutrophication due to phosphorus recycling in relation to lake morphometry, temperature, and macrophytes. Ecology 86(1): 210-219.

GEOMATICA ALGORITHM REFERENCE. 2003. PCI Geomatics. 50 West Wilmot Street, Reichmond Hill, Ontario Canada, L4B 1 M5.

GOLDEN SOFTWARE. 2013. GraphPad PRISM 5 for Windows. Version 5.01. Golden.

GOLDER. 2010. Anexo IV - Geologia. Estudo de Impacto Ambiental, EIA Projeto Ferro Carajas S11D.

GUIMARÃES JTF ET AL. 2014. Source and distribution of pollen and spores in surface sediments of a plateau lake in south-eastern Amazonia. Quatern Int 352: 181-196.

GUIMARÃES JTF ET AL. 2017. Modern pollen rain as a background for palaeoenvironmental studies in the Serra dos Carajás, southeastern Amazonia. The Holocene 27(8): 1055-1066.

HÅKANSON L. 1981. A manual of lake morphometry. New York: Springer-Verlag, p. 78.

HÅKANSON L. 1999. Water pollution - methods and criteria to rank, model and remediate chemical threats to aquatic ecosystems. Leiden: Backhuys Publishers, p. 165.

HÅKANSON L. 2004. Lakes: form and function. The Blackburn press, New Jersey, p. 201.

HÅKANSON L AND JANSSON M. 1983. Principles of Lake Sedimentology. New York: Springer-Verlag, p. 148.

HUTCHINSON EG. 1957. A Treatise on Limnology. 1. New York: J Wiley \& Sons INC.

IMAZON. 2003. Fatos Florestais da Amazônia. Belém: Imazon, p. 110.

JUNK WJ. 1997. Structure and function of the large Central Amazonian river floodplains: Synthesis and Discussion. In: Junk WJ (Ed), The Central Amazon Floodplain. Berlin: Springer-Verlag 126: 455-468.

JUNK WJ, BARLEY PB AND SPARKS RE. 1989. The flood pulse concept in river floodplain systems. Can Spec Publ Fish Aquat Sci 106: 110-127.

KIRK JTO. 2011. Light and Photosynthesis in Aquatic Ecosystems. 3rd ed., Cambridge: Cambridge University Press, p. 610.

LAMPARELLI MC. 2004. Degrees of trophy in water bodies of São Paulo: Evaluation of monitoring methods. Doctoral Thesis, Institute of Biosciences, University of São Paulo, São Paulo, $235 \mathrm{p}$.

LANE SN, REID SC, TAYEFI V, YU D AND HARDY RJ. 2007. Interactions between sediment delivery, channel change, climate change and flood risk in a temperate upland environment. Earth Surf Proc Land 32: 429-446.

LESACK LF AND MELACK JM. 1995. Flooding hydrology and mixture dynamics of lake water derived from multiple sources in an Amazon floodplain lake. Water Resour Res 31: 329-345.

LOPES PM, CALIMAN A, CARNEIRO LS, BINI LM, ESTEVES FA, FARJALLA V AND BOZELLI R. 2011. Concordance among assemblages of upland Amazonian lakes and structuring role of spatial and environmental factors. Ecol Indic 11(5): 1171-1176.

LUHTALA H AND TOLVANEN H. 2013. Optimizing the Use of Secchi Depth as a Proxy for Euphotic Depth in Coastal Waters: An Empirical Study from the Baltic Sea. ISPRS Int J Geo-Inf 2: 1153-1168.

MACAMBIRA MJB AND LAFON J-M. 1995. Geocronologia da Província mineral de Carajás: síntese dos dados e novos desafios. Bol Mus Para Emílio Goeldi, Série Cienc Terra 7: $263-288$.

MAGYAR N, HATVANI IG, SZÉKELY IK, HERZIG A, DINKA M AND KOVÁCS J. 2013. Application of multivariate statistical methods in determining spatial changes in water quality in the Austrian part of Neusiedler See. Ecol Eng 55: 82-92.

MAURITY CW AND KOTSCHOUBEY B. 1995. Evolução recente da cobertura de alteração no Platô N1 - Serra dos Carajás-PA. Degradação, pseudocarstificação, espeleotemas. Bol Mus Para Emílio Goeldi, série Cienc Terra 7: 331-362.

MOLISANI MM, BARROSO HS, BECKER H, MOREIRA MOP, HIJO CAG, MONTE TM AND VASCONCELLO GH. 2010. Trophic state, phytoplankton assemblages and limnological diagnosis of the Castanhão Reservoir, CE, Brazil. Acta Limnol Bras 22(1): 1-12.

MOSES SA, JANAKI L, JOSEPH S, JUSTUS J AND VIMALA RS. 2011. Influence of lake morphology on water quality. Environ Monit Assess 182: 443-454.

MORAIS RP, OLIVEIRA LG, LATRUBESSE EM AND PINHEIRO RCD. 2005. Morfometria de sistemas lacustres da planície aluvial do médio rio Araguaia. Acta Sci, Biol Sci 27(3): 203-213.

NÕGES T. 2009. Relationships between morphometry, geographic location and water quality parameters of European lakes. Hydrobiologia 633(1): 33-43.

NUNES JA, SCHAEFER CEGR, FERREIRA JÚNIOR WG, NERI AV, CORREA GR AND ENRIGHT NJ. 2015. Soilvegetation relationships on a banded ironstone 'island', Carajás Plateau, Brazilian Eastern Amazonia. An Acad Bras Cienc 87: 2097-2110.

OLSZEWSKI WJ, WIRTH KR, GIBBS AK AND GAUDETTE HE. 1989. The age, origin, and tectonics of the Grão Pará Group and associated rocks, Serra dos Carajás, Brazil: archean continental vulcanism and rifting. Precambrian Res 42(3-4): 229-254.

PANOSSO RF, MUEHE D AND ESTEVES FDA. 1995. Morphological characteristics of an Amazon floodplain 
lake (Lake Batata, Pará State, Brazil). Amazoniana 8(3-4): 245-258.

PREISENDORFER RW. 1986. Secchi disk science: Visual optics of natural waters. Limnol Oceanogr 31: 909-926.

RÄMÖ OT, DALL'AGNOL R, MACAMBIRA MJB, LEITE AAS AND DE OLIVEIRA DC. 2002. $1.88 \mathrm{Ga}$ oxidized A-Type granites of the Rio Maria Region, eastern Amazonian craton, Brazil: Positively Anorogenic! J Geol 110: 603-610.

REZENDE NP AND BARBOSA AL DE M. 1972. Relatório de pesquisa de minério de ferro, Distrito Ferrífero da Serra dos Carajás, Estado do Pará. Belém: AMZA 1: 248.

SAHOO PK, SOUZA FILHO PWM, GUIMARÃES JTF, SILVA MS, COSTA FR, MANES CLO, OTI D, SILVA JUNIOR RO AND DALL'AGNOL R. 2015. Use of multiproxy approaches to determine the origin and depositional processes in modern lacustrine sediments: Carajás Plateau, Southeastern Amazon, Brazil. Appl Geochem 52: 130-146.

SAHOO PK ET AL. 2017. Limnological characteristics and planktonic diversity of five tropical upland lakes from Brazilian Amazon. Ann Limnol-Int J Lim 53: 467-483.

SAHOO PK ET AL. 2016b. Geochemistry of upland lacustrine sediments from Serra dos Carajás, Southeastern Amazon, Brazil: implications for catchment weathering, provenance, and sedimentary processes. J South Am Earth Sci 72: 178-190.

SAHOO PK ET AL. 2016a. Influence of Seasonal Variation on the Hydro-biogeochemical characteristics of two upland lakes of the Southeastern Amazon, Brazil. An Acad Bras Cienc 88: 2211-2227.

SAUCIER WJ. 1955. Principles of Meteorological Analysis. University of Chicago Press, 438 p.

SCHNURRENBERGER D, RUSSELL J AND KERRY K. 2003. Classification of lacustrine sediments based on sedimentary components. J Paleolimnol 29: 141-154.

SILVA JÚNIOR RO, QUEIROZ JCB, FERREIRA DBS, LIMA AT, SOUZA FILHO PWM, GUIMARÃES JTF AND ROCHA EP. 2017. Estimativa de precipitação e vazões médias para a bacia hidrográfica do rio Itacaiúnas
(BHRI), Amazônia Oriental, Brasil. Rev Bras Geofís 10: 1638-1654.

SKIRYCZ A, CASTILHO A, CHAPARRO C, CARVALHO N, TZOTZOS G AND SIQUEIRA JO. 2014. Canga biodiversity, a matter of mining. Front Plant Sci 5: 1-9.

SMITH VH, FOSTER BL, GROVER JP, HOLT RD, LEIBOLD MA AND DENOYELLES F. 2005. Phytoplankton species richness scales consistently from laboratory microcosms to the world's oceans. P Natl Acad Sci USA 102(12): 43934396.

SOUZAFILHO PWM, GUIMARÃES JTF, SILVAMS, COSTA FR, SAHOO PK, MAURITY CW AND DALL'AGNOL R. 2016. Basin Morphology and seismic stratigraphy of an upland lake from Serra dos Carajás, southeastern Amazon, Brazil. Bol Mus Para Emílio Goeldi. Ser Ciênc Nat 11: 71-83.

SPERLING E. 1999. Morfologia de lagos e represas. Belo Horizonte: DESA/UFMG, p. 137.

STATSOFT. 2009. STATISTICA (data analysis software system), version 8. 2009.

STEFANIDIS K AND PAPASTERGIADOU E. 2012. Relationships between lake morphometry, water quality, and aquatic macrophytes, in Greek Lakes. Fresen Environ Bull 21(10): 3018-3026.

THIENEMANN A. 1927. Der Bau des Seebeckens in seiner Bedeutung für den Ablauf des Lebens im See. Verh ZoolBot Ges Wien 77: 87-91.

TIMMS BV. 1992. Lake Geomorphology. Adelaide: Gleneagles, p. 180.

TOLBERT GE, TREMAINE JW, MELCHER GC AND GOMES CB. 1971. The recently discovered Serra dos Carajás iron deposit, northern Brazil. Econ Geol 66(7): 985-994.

WETZEL 2001. Limnology - Lake and River Ecosystems. 3rd ed., San Diego: Academic Press, p. 1006.

\section{SUPPLEMENTARY MATERIAL}

TABLE SI - Studied lakes on depth, area, volume ( $\mathrm{m}^{3}$ and \%). 